\title{
BMJ Open Association of intrinsic and extrinsic motivating factors with physician burnout and job satisfaction: a nationwide cross-sectional survey in Taiwan
}

Yu-Chi Tung (D , , Ying-Yi Chou, ${ }^{1}$ Yu-Hsuan Chang, ${ }^{2,3}$ Kuo-Piao Chung ${ }^{1}$

To cite: Tung Y-C, Chou Y-Y, Chang $\mathrm{Y}-\mathrm{H}$, et al. Association of intrinsic and extrinsic motivating factors with physician burnout and job satisfaction: a nationwide cross-sectional survey in Taiwan. BMJ Open 2020;10:e035948. doi:10.1136/ bmjopen-2019-035948

- Prepublication history for this paper is available online. To view these files, please visit the journal online (http://dx.doi org/10.1136/bmjopen-2019035948).

Received 23 November 2019 Revised 22 January 2020 Accepted 10 February 2020

\section{Check for updates}

C Author(s) (or their employer(s)) 2020. Re-use permitted under CC BY-NC. No commercial re-use. See rights and permissions. Published by BMJ.

${ }^{1}$ Institute of Health Policy and Management, College of Public Health, National Taiwan University, Taipei, Taiwan

${ }^{2}$ Planning Division, National Health Insurance Administration, Taipei, Taiwan

${ }^{3}$ Department of Gerontological Health Care, National Taipei University of Nursing and Health Sciences, Taipei, Taiwan

Correspondence to Professor Kuo-Piao Chung; kpchung@ntu.edu.tw

\section{ABSTRACT}

Objective The aim of this study was to systematically and simultaneously examine the association of intrinsic and extrinsic motivating factors with physician burnout and job dissatisfaction.

Design A nationally representative survey was fielded from September to November 2017.

Setting Hospitals and clinics throughout Taiwan.

Participants A total of 6674 physicians.

Main exposure measure The main exposure measures were intrinsic motivators (sense of calling, personally rewarding hours per day and meaningful, long-term relationships with patients) and extrinsic motivators (income, work hours, autonomy, and pay-for-performance (P4P) and bundled payment initiatives).

Main outcome measures The main outcome measures were physician burnout and job dissatisfaction.

Results A total of 1152 physicians returned the surveys. More sense of calling and personally rewarding hours per day were associated with less physician burnout (OR 0.16 , $95 \% \mathrm{Cl} 0.10$ to 0.26 and $0 \mathrm{R} 0.25,95 \% \mathrm{Cl} 0.13$ to 0.47 , respectively) and job dissatisfaction (0R $0.35,95 \% \mathrm{Cl} 0.21$ to 0.57 and $\mathrm{OR} 0.46,95 \% \mathrm{Cl} 0.26$ to 0.83 , respectively). Longer work hours were associated with more physician burnout (OR 2.67, 95\% Cl 1.54 to 4.63) and job dissatisfaction (OR 1.71, $95 \% \mathrm{Cl} 1.05$ to 2.79 ). Not receiving $\mathrm{P} 4 \mathrm{P}$ bonuses from their organisations was associated with more physician burnout (OR 1.56, 95\% $\mathrm{Cl} 1.02$ to 2.38). Not sharing the losses from caring for patients included in the bundled payment system was associated with less physician burnout (OR 0.59, 95\% $\mathrm{Cl} 0.36$ to 0.97$)$.

Conclusions Fostering a healthcare work environment that supports intrinsic motivation and improves work hours may reduce physician burnout and job dissatisfaction. Rewarding physicians fairly and equitably may prevent them from feeling burned out. Value-based care delivery and payment model innovations, such as bundled payments, may encourage healthcare professionals to coordinate care through the standardisation of care to decrease burnout.

\section{INTRODUCTION}

The Triple Aim of improving the health of the population, enhancing the patient
Strengths and limitations of this study

- This study used a nationwide physician survey to examine the association of intrinsic motivators (sense of calling, personally rewarding hours per day and meaningful, long-term relationships with patients) and extrinsic motivators (income, work hours, autonomy, and pay-for-performance and bundled payment initiatives) with physician burnout and job dissatisfaction.

- Case sampling weights were calculated from relevant physician characteristics in the final data set to adjust for non-response bias.

- The data were cross sectional, so the results reflect the association of intrinsic and extrinsic motivating factors with physician burnout and job satisfaction, but causality could not be determined.

experience of care and reducing the per capita cost of healthcare is widely accepted as a compass by which to optimise health system performance. ${ }^{1} \quad$ Nevertheless, physicians report burnout and dissatisfaction. Physician burnout is a growing concern around the world, such as in the USA and other countries in the Organisation for Economic Cooperation and Development and in Taiwan. ${ }^{23}$ Based on national surveys, the burnout rate in a 2011 US national physician sample was $45.5 \%,{ }^{4}$ and that in a 2011 Japan national neurosurgeon and neurologist survey was $21.6 \% .^{5}$ In Taiwan, there has been no national survey, but one study found that the physician burnout rate in 2012 in a Taiwan regional hospital was $38.6 \% .^{6}$

Recent studies have suggested that the Triple Aim be expanded to the Quadruple Aim by adding the goal of improving the work life (burnout and dissatisfaction) of physicians and other healthcare workers. ${ }^{7-10}$ Physician burnout is associated with selfreported medical errors or suboptimal care 
quality. ${ }^{10}$ Physician job dissatisfaction is associated with less patient satisfaction. ${ }^{11}$ Understanding the factors that affect physician burnout and job satisfaction is important for developing effective initiatives to improve physician work life. To the best of our knowledge, few studies have used a nationwide physician survey to systematically and simultaneously examine the association of intrinsic and extrinsic motivating factors with physician burnout and job dissatisfaction.

The organismic integration theory of behavioural science proposes that individuals are intrinsically motivated and integrate intrinsic and extrinsic motivating factors while they pursue well-being. ${ }^{4213}$ Intrinsic motivation refers to doing something because it is inherently interesting or enjoyable, and extrinsic motivation refers to doing something because it leads to a dividable outcome. Extrinsic motivation is further divided into four regulatory styles, called external regulation, introjection, identification and integration. ${ }^{12}$ One previous study using subjective measures of intrinsic and extrinsic motivation found that intrinsic motivation and extrinsic motivation (integrated regulation and introjected regulation) were associated with physician burnout and job satisfaction. ${ }^{14}$ Another prior study found that intrinsic motivators (sense of calling and personally rewarding hours per day) and extrinsic motivators (income) were associated with physician job satisfaction. ${ }^{4}$ Prior studies that did not adjust for intrinsic motivators found that long work hours were associated with physician job dissatisfaction, ${ }^{15}$ and that value-based payments were associated with less physician burnout. ${ }^{16}$ However, thus far, no research has simultaneously examined the association of intrinsic motivators and extrinsic motivators (income, work hours and value-based payments) with physician burnout and job satisfaction.

Taiwan's National Health Insurance (NHI) system has been implemented since March 1995. The National Health Insurance Administration (NHIA) is the sole insurer. Each enrollee pays a premium to enjoy comprehensive benefits and a low copayment that enable them to go freely to any hospital or clinic, with lower copayments for visits with a referral. Almost all providers have contracts with the NHIA. Physicians are classified as being either hospital physicians or clinic physicians. Hospital physicians are employed by hospitals and treat both outpatients and inpatients. Clinic physicians are owners or employees of the clinics and only treat outpatients. Physician salaries that are paid by their employers include fixed and variable components to encourage physicians to strive for higher levels of performance. ${ }^{17}$ The NHIA reimburses providers mainly on a fee-for-service basis, and partially implements value-based payments, including pay-for-performance (P4P) for several diseases and bundled payments for several inpatient medical conditions. Some clinics/hospitals treating $\mathrm{P} 4 \mathrm{P}$ patients do not pay their individual physician bonuses from the $\mathrm{P} 4 \mathrm{P}$ programme. Most hospitals adopt clinical pathways and gainsharing plans in response to bundled payments. ${ }^{17}$ Regarding gainsharing plans, some hospitals require physicians to share the losses incurred in the bundled payment system. Therefore, their physicians might think their performance and efforts are not rewarded fairly and equitably, and this may cause them to feel burned out and dissatisfied based on the organismic integration theory. ${ }^{12}$ On the other hand, if hospitals do not require physicians to share the losses, physicians might report less burnout because the clinical pathways are effective interventions for improving teamwork and increasing the organisational level of care processes, which then decreases the risk of physician burnout. ${ }^{18}$

This study uses data from a nationally representative survey of Taiwanese physicians to systematically investigate the association of intrinsic motivators and extrinsic motivators (income, work hours and value-based payments) with physician burnout and job dissatisfaction.

\section{METHODS}

\section{Data source}

An anonymous, self-administered questionnaire was mailed to 6674 practising physicians who were randomly sampled from the physician population $(\mathrm{n}=43969)$ practising under the NHI system. To achieve a $95 \%$ confidence level and a 3\% margin of error (ie, generally accepted levels for a random population study), the minimum required survey respondents were calculated to be 1042 using the standard formula: $\frac{Z^{2} p(1-p) N}{Z^{2} p(1-p)+(N-1) e^{2}}$, where $Z$ is the statistical Z-score that corresponds to the confidence level, $\mathrm{p}$ is $0.5, \mathrm{~N}$ is the population size and e is margin of error. ${ }^{19-22}$ The survey was conducted between September and November 2017.

A total of 1152 physicians returned the surveys, for a response rate of $17.3 \%$. Based on the physician population, the results are confident to $\pm 2.85 \%$ margin of error at the $95 \%$ confidence level. Case sampling weights were calculated from relevant physician characteristics in the final data set to adjust for non-response bias. ${ }^{43}$ The respondent sample was weighted to the physician population in terms of gender, age, practice region and practice site. These variables were chosen because national data on their joint distribution in the study population were available. After the weighting, a comparison of the respondent characteristics (gender, age, practice region and practice site) with those of the study population showed no significant difference.

The survey questionnaire was used to examine the association of intrinsic and extrinsic motivators with physician burnout and job dissatisfaction, after adjusting for attitudes towards the NHI and sociodemographic characteristics. The content validity was based on results from a review of the literature, ${ }^{4524-34}$ an expert panel examination and feedback, and pilot testing.

\section{Variables}

\section{Dependent variables}

The dependent variables were physician burnout and job satisfaction. Physician burnout was assessed with a validated short form of the Maslach Burnout Inventory 
(MBI), using the following two questions answered on a seven-point Likert scale 3031 33: "I feel burned out from my work" (MBI emotional exhaustion) and "I have become more callous toward people since I took this job" (MBI depersonalisation). Each item was recoded into a binary variable: no (never, a few times a year, once a month or less, a few times a month) versus yes (once a week, a few times a week, every day). Overall burnout was defined as high burnout, defined as a yes answer for one or both of the items documented by other studies in the literature. ${ }^{243031333536}$ Although the current standard for burnout assessment is the MBI, a well-validated instrument consisting of 22 items answered on a seven-point Likert scale, the full length of the MBI limits the feasibility of its use in large physician surveys addressing multiple content areas within space constraints. ${ }^{30} 3133$ Therefore, large physician surveys have used single-item burnout assessment tools. ${ }^{41}$ Job satisfaction was measured with an item measuring overall satisfaction that has been used in previous studies. ${ }^{4} 15252734$ This instrument uses a fivepoint Likert scale that ranges from 'very dissatisfied' to 'very satisfied.'

\section{Independent variables}

The independent variables were intrinsic and extrinsic motivating factors. The intrinsic motivators included sense of calling, personally rewarding hours per day and having meaningful, long-term relationships with patients. ${ }^{4}$ A sense of calling was measured through a single-item measure that has been used in previous studies: "For me, the practice of medicine is a calling." 32 This instrument uses a five-point Likert scale that ranges from 'strongly agree' to 'strongly disagree.' Personally rewarding hours per day was estimated in response to the following prompt: "Please estimate how many hours you spend in a typical day at work on activities that you find personally rewarding." 4 The responses were divided into $<2.5,2.5-5.0,5.0-7.5$ and $\geq 7.5$ hours. The frequency of long-term relationships with patients was assessed with the following question: "With respect to your patients, with how many do you have a meaningful, long-term relationship?" Responses included none, a few, many and most.

The extrinsic motivators included monthly income $(<$ New Taiwan (NT)\$200000, NT\$200 000-299999, $\geq$ NT $\$ 300000$ (NT\$32=US\$1)), number of work hours a week ( $\leq 40,41-59, \geq 60)$, professional autonomy and valuebased payments. Physicians' autonomy was measured by the perceptions of their ability to provide needed outpatient/inpatient services to their patients. ${ }^{25} 27$ The instrument used a five-point Likert scale that ranged from strongly agree to strongly disagree. The value-based payments included $\mathrm{P} 4 \mathrm{P}$ and bundled payments. The $\mathrm{P} 4 \mathrm{P}$ exposure was measured as whether the respondents treated $\mathrm{P} 4 \mathrm{P}$ patients and whether the respondents who reported that they treated $\mathrm{P} 4 \mathrm{P}$ patients received bonuses. The exposure to bundled payments was measured as whether the respondents cared for patients included in the bundled payment system and whether the respondents who reported that they cared for patients included in the bundled payment system were required to share the losses.

\section{Covariates}

The covariates were attitudes toward the NHI and demographic characteristics. The attitudes toward the NHI included attitudes toward community value as identified regulation and personal benefit as integrated regulation. The identified regulation under NHI was measured with the following question: "The NHI is necessary for public health"; the integrated regulation was measured with the following question: "The NHI is a favorable system to me." ${ }^{29}$ The instrument used a five-point Likert scale that ranged from strongly agree to strongly disagree. Based on the organismic integration theory, the identified regulation and integrated regulation are subtypes of extrinsic motivation. A form of extrinsic motivation is regulation through identification. Integration occurs when identified regulations have been fully assimilated to the self. This occurs through self-examination and bringing new regulations into congruence with one's other values and needs. ${ }^{12}$ The demographic characteristics included gender, age, education level, practice site, specialty, years in practice and practice location.

\section{Statistical analysis}

Multivariate binary logistic regression was used to analyse the association of intrinsic motivators and extrinsic motivators with physician burnout and job dissatisfaction, after adjusting for attitudes towards the NHI and demographic characteristics. A small amount of missing data $(0.2 \%-3.2 \%$ of each survey item) was imputed using multiple imputation methods. ${ }^{47}$ For physician burnout, the responses were dichotomised by treating burnout as one group (coded 1) and non-burnout as the other group (coded 0). For job dissatisfaction, the responses were dichotomised by treating 'very dissatisfied and dissatisfied' as one group (coded 1) and the remaining responses as the other group (coded 0). SAS software, V.9.4 (SAS Institute), was adopted for the analysis. All statistical tests were two-tailed and used a type I error rate of 0.05 .

\section{Patient and public involvement}

No patients were involved in this study. The public has not been involved in the development of the research or in the study design. The study results will be disseminated to respondents via newsletters and publications.

\section{RESULTS}

Table 1 presents the physicians' demographics, job characteristics, burnout and job satisfaction. More than half $(79.4 \%)$ of the physicians were male, $63.3 \%$ were 40 years old or above, $34.8 \%$ worked at clinics, $21.8 \%$ had an internal medicine certificate and $45.1 \%$ had at least 20 years in practice. Medical practice was perceived to be a calling by $71.3 \%$ of the physicians, and $89.8 \%$ of the 
Table 1 Physician characteristics, burnout and job satisfaction $(n=1152)$

\begin{tabular}{|c|c|c|}
\hline Variables & $\mathbf{n}$ & $\%$ \\
\hline \multicolumn{3}{|l|}{ Demographic characteristics } \\
\hline \multicolumn{3}{|l|}{ Gender } \\
\hline Male & 915 & 79.4 \\
\hline Female & 237 & 20.6 \\
\hline \multicolumn{3}{|l|}{ Age, years } \\
\hline$<30$ & 97 & 8.4 \\
\hline $30-39$ & 326 & 28.3 \\
\hline $40-49$ & 274 & 23.8 \\
\hline $50-59$ & 255 & 22.1 \\
\hline$\geq 60$ & 200 & 17.4 \\
\hline \multicolumn{3}{|l|}{ Practice site } \\
\hline Clinic & 401 & 34.8 \\
\hline District hospital & 121 & 10.5 \\
\hline Regional hospital & 274 & 23.8 \\
\hline Academic medical centre & 356 & 30.9 \\
\hline \multicolumn{3}{|l|}{ Specialties } \\
\hline Internal medicine & 251 & 21.8 \\
\hline Surgery & 131 & 11.4 \\
\hline Obstetrics and gynaecology & 77 & 6.7 \\
\hline Paediatrics & 127 & 11.0 \\
\hline \multicolumn{3}{|l|}{ Years in practice } \\
\hline$<10$ & 308 & 26.7 \\
\hline $10-19$ & 325 & 28.2 \\
\hline$\geq 20$ & 519 & 45.1 \\
\hline \multicolumn{3}{|l|}{ Practice location } \\
\hline Taipei & 432 & 37.5 \\
\hline Northern & 140 & 12.1 \\
\hline Central & 217 & 18.8 \\
\hline Southern & 147 & 12.8 \\
\hline Kao-Ping & 191 & 16.6 \\
\hline Eastern & 25 & 2.2 \\
\hline
\end{tabular}

Attitudes towards the NHI

The NHI is necessary for public health

$\begin{array}{lll}\text { Strongly agree or agree } & 817 & 70.9\end{array}$

$\begin{array}{lll}\text { Neutral } & 204 & 17.7\end{array}$

Strongly disagree or disagree $131 \quad 11.4$

The NHI is a favourable system to me

Strongly agree or agree 622

Neutral $\quad 329 \quad 28.6$

Strongly disagree or disagree $\quad 201 \quad 17.4$

Intrinsic motivators

Practice of medicine is a calling

\begin{tabular}{|lll}
\hline Strongly agree or agree & 822 & 71.3 \\
\hline Neutral & 206 & 17.9 \\
\hline Strongly disagree or disagree & 124 & 10.8 \\
\hline Personally rewarding hours per day & & \\
\hline
\end{tabular}

Continued
Table 1 Continued

\begin{tabular}{cll}
\hline Variables & $\mathbf{n}$ & $\%$ \\
\hline$<2.5$ & 117 & 10.2 \\
$2.5-5.0$ & 447 & 38.8 \\
$5.0-7.5$ & 394 & 34.2 \\
$\geq 7.5$ & 194 & 16.8
\end{tabular}

Meaningful, long-term relationships with patients

$\begin{array}{lrr}\text { Most } & 69 & 6.0 \\ \text { Many } & 437 & 37.9 \\ \text { A few } & 512 & 44.5 \\ \text { None } & 134 & 11.6\end{array}$

Extrinsic motivators

Monthly income, NT\$

$\begin{array}{lll}<200000 & 568 & 49.3 \\ 200000-299999 & 321 & 27.9 \\ \geq 300000 & 263 & 22.8\end{array}$

Work hours a week

$\begin{array}{lll}\leq 40 & 209 & 18.1 \\ 41-59 & 501 & 43.5 \\ \geq 60 & 442 & 38.4\end{array}$

Am able to provide needed outpatient services

\begin{tabular}{|c|c|c|}
\hline Strongly agree or agree & 999 & 86.7 \\
\hline Neutral & 131 & 11.4 \\
\hline Strongly disagree or disagree & 22 & 1.9 \\
\hline \multicolumn{3}{|c|}{ Am able to provide needed inpatient services } \\
\hline Strongly agree or agree & 609 & 52.9 \\
\hline Neutral & 93 & 8.1 \\
\hline Strongly disagree or disagree & 20 & 1.7 \\
\hline Not applicable & 430 & 37.3 \\
\hline \multicolumn{3}{|l|}{ Under pay-for-performance } \\
\hline No & 841 & 73.0 \\
\hline Yes & 311 & 27.0 \\
\hline Receive bonus & 123 & 39.5 \\
\hline Do not receive bonus & 175 & 56.3 \\
\hline Missing & 13 & 4.2 \\
\hline \multicolumn{3}{|l|}{ Under bundled payments } \\
\hline No & 861 & 74.7 \\
\hline Yes & 291 & 25.3 \\
\hline Am required to share losses & 123 & 42.3 \\
\hline $\begin{array}{l}\text { Am not required to share } \\
\text { losses }\end{array}$ & 168 & 57.7 \\
\hline \multicolumn{3}{|l|}{ Burnout } \\
\hline Yes & 330 & 28.6 \\
\hline No & 822 & 71.4 \\
\hline \multicolumn{3}{|l|}{ Job dissatisfaction } \\
\hline Yes & 414 & 35.9 \\
\hline No & 738 & 64.1 \\
\hline
\end{tabular}

NT\$32 equaled \$1 in 2017.

NHI, National Health Insurance; NT, New Taiwan. 
Table 2 Physician burnout and job dissatisfaction by physician characteristics $(n=1152)$

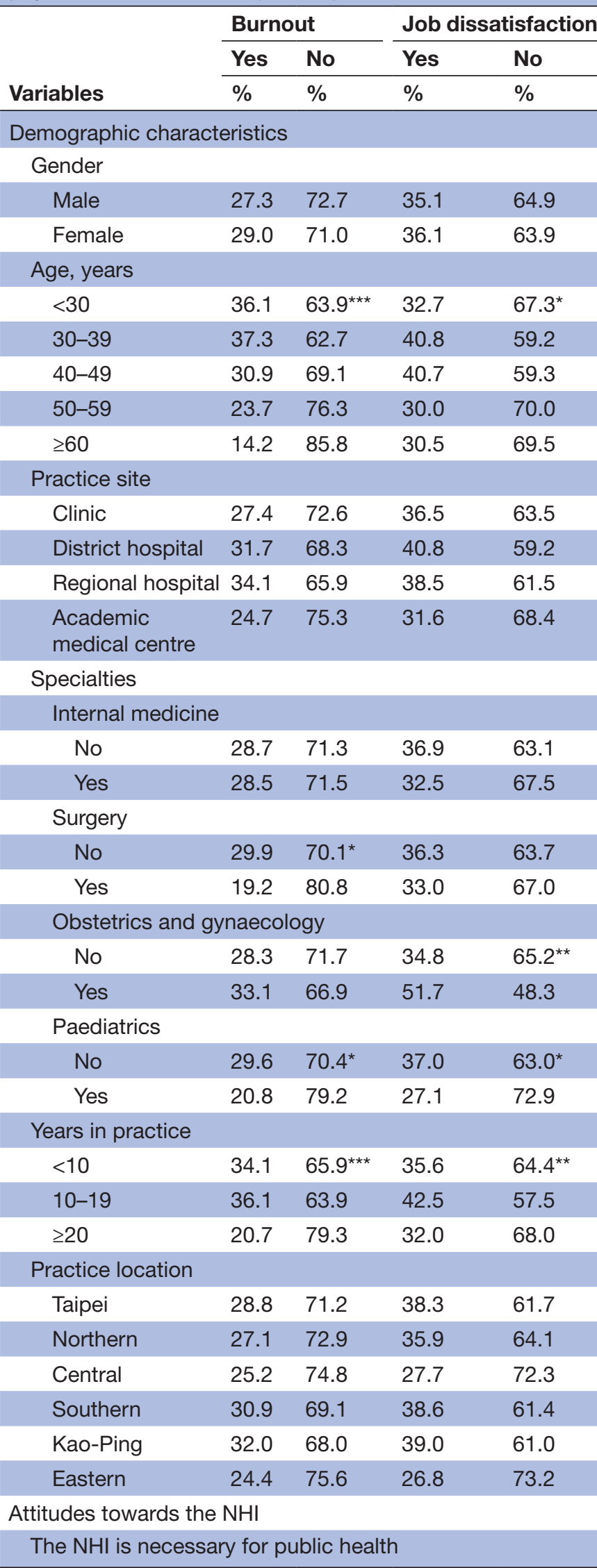

Continued
Table 2 Continued

Variables

\begin{tabular}{lllll}
\multicolumn{2}{l}{ Burnout } & & \multicolumn{2}{l}{ Job dissatisfaction } \\
\cline { 1 - 2 } \cline { 5 - 5 } Yes & No & & Yes & No \\
\hline$\%$ & $\%$ & & $\%$ & $\%$
\end{tabular}

Strongly agree or $23.5 \quad 76.5^{\star \star \star} \quad 26.9 \quad 73.1^{\star \star \star}$ agree

$\begin{array}{lllll}\text { Neutral } & 31.5 & 68.5 & 47.9 & 52.1\end{array}$

$\begin{array}{lllll}\text { Strongly disagree } & 56.2 & 43.8 & 73.6 & 26.4\end{array}$
or disagree

The $\mathrm{NHI}$ is a favourable system to me

Strongly agree or $21.3 \quad 78.7^{\star \star \star} \quad 22.1 \quad 77.9^{\star \star \star}$ agree

$\begin{array}{lllll}\text { Neutral } & 30.2 & 69.8 & 44.3 & 55.7\end{array}$

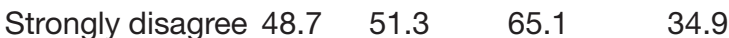
or disagree

Intrinsic motivators

Practice of medicine is a calling

Strongly agree or $18.8 \quad 81.2^{\star \star \star} \quad 29.1 \quad 70.9^{\star \star \star}$ agree

$\begin{array}{lllll}\text { Neutral } & 41.6 & 58.4 & 43.4 & 56.6\end{array}$

$\begin{array}{llll}\text { Strongly disagree } 72.0 & 28.0 & 68.6 & 31.4\end{array}$

or disagree

Personally rewarding hours per day

$\begin{array}{lllll}<2.5 & 55.1 & 44.9^{* \star *} & 58.8 & 41.2^{\star * *} \\ 2.5-5.0 & 33.6 & 66.4 & 39.6 & 60.4 \\ 5.0-7.5 & 20.7 & 79.3 & 27.7 & 72.3 \\ \geq 7.5 & 17.5 & 82.5 & 30.4 & 69.6\end{array}$

Meaningful, long-term relationships with patients

$\begin{array}{lllll}\text { Most } & 29.7 & 70.3^{\star \star \star} & 36.1 & 63.9\end{array}$

$\begin{array}{lllll}\text { Many } & 23.9 & 76.1 & 34.5 & 65.5\end{array}$

$\begin{array}{lllll}\text { A few } & 28.5 & 71.5 & 35.6 & 64.4\end{array}$

$\begin{array}{lllll}\text { None } & 44.3 & 55.7 & 41.5 & 58.5\end{array}$

Extrinsic motivators

Monthly income, NT\$

$\begin{array}{lllll}<200000 & 31.9 & 68.1^{\star} & 39.3 & 60.7^{\star} \\ 200000-299999 & 28.5 & 71.5 & 35.7 & 64.3 \\ \geq 300000 & 21.8 & 78.2 & 28.9 & 71.1\end{array}$

Work hours a week

$\begin{array}{lllll}\leq 40 & 17.4 & 82.6^{\star \star \star} & 27.8 & 72.2^{\star} \\ 41-59 & 28.7 & 71.3 & 36.8 & 63.2 \\ \geq 60 & 33.9 & 66.1 & 38.8 & 61.2\end{array}$

Am able to provide needed outpatient services

$\begin{array}{llll}\text { Strongly agree or } 27.8 & 72.2 & 36.6 & 63.4\end{array}$ agree

$\begin{array}{lllll}\text { Neutral } & 33.4 & 66.6 & 29.4 & 70.6\end{array}$

$\begin{array}{llll}\text { Strongly disagree } 39.8 & 60.2 & 44.4 & 55.6\end{array}$

or disagree

Am able to provide needed inpatient services

Continued 
Table 2 Continued

\begin{tabular}{|c|c|c|c|c|}
\hline \multirow[b]{3}{*}{ Variables } & \multicolumn{2}{|c|}{ Burnout } & \multicolumn{2}{|c|}{ Job dissatisfaction } \\
\hline & Yes & No & Yes & No \\
\hline & $\%$ & $\%$ & $\%$ & $\%$ \\
\hline $\begin{array}{l}\text { Strongly agree or } \\
\text { agree }\end{array}$ & 27.2 & 72.8 & 34.5 & 65.5 \\
\hline Neutral & 39.5 & 60.5 & 36.7 & 63.3 \\
\hline $\begin{array}{l}\text { Strongly disagree } \\
\text { or disagree }\end{array}$ & 31.3 & 68.7 & 51.5 & 48.5 \\
\hline Not applicable & 28.2 & 71.8 & 37.1 & 62.9 \\
\hline \multicolumn{5}{|c|}{ Under pay-for-performance } \\
\hline No & 28.4 & $71.6^{*}$ & 37.0 & 63.0 \\
\hline $\begin{array}{l}\text { Yes, receive } \\
\text { bonus }\end{array}$ & 21.9 & 78.1 & 27.9 & 72.1 \\
\hline $\begin{array}{l}\text { Yes, do not } \\
\text { receive bonus }\end{array}$ & 35.3 & 64.7 & 35.7 & 64.3 \\
\hline Yes, missing & 17.0 & 83.0 & 45.9 & 54.1 \\
\hline \multicolumn{5}{|c|}{ Under bundled payments } \\
\hline No & 30.4 & 69.6 & 36.1 & 63.9 \\
\hline $\begin{array}{l}\text { Yes, be required } \\
\text { to share losses }\end{array}$ & 24.5 & 75.5 & 40.9 & 59.1 \\
\hline $\begin{array}{l}\text { Yes, be not } \\
\text { required to share } \\
\text { losses }\end{array}$ & 22.9 & 77.1 & 31.6 & 68.5 \\
\hline
\end{tabular}

NT\$32 equaled \$1 in 2017.

${ }^{*} \mathrm{p}<0.05 ;{ }^{* \star} \mathrm{p}<0.01 ;{ }^{* * *} \mathrm{p}<0.001$.

NHI, National Health Insurance; NT, New Taiwan.

physicians experienced at least 2.5 personally rewarding hours a day. Eighty-eight per cent $(88.4 \%)$ of the physicians had meaningful, long-term relationships with at least a few patients. Approximately half $(50.7 \%)$ of the physicians earned a monthly income of at least NT $\$ 200000$, and $38.4 \%$ worked at least 60 hours a week. Twenty-seven per cent $(27.0 \%)$ of the physicians indicated that they treated $\mathrm{P} 4 \mathrm{P}$ patients. Among the physicians who treated $\mathrm{P} 4 \mathrm{P}$ patients, $56.3 \%$ did not receive bonuses. Approximately $25.3 \%$ of the physicians indicated that they cared for patients included in the bundled payment system. Among the physicians who cared for patients included in the bundled payment system, $42.3 \%$ were required to share the losses. Twenty-nine per cent $(28.6 \%)$ of the physicians reported feeling burned out. Thirty-six per cent $(35.9 \%)$ of the physicians were very dissatisfied or dissatisfied with their job.

In the univariable analysis (table 2), a $\chi^{2}$ analysis showed a significant association of intrinsic and extrinsic motivators with physician burnout and job satisfaction $(p<0.05)$. Sense of calling, personally rewarding hours per day, long-term relationships with patients, income, work hours and $\mathrm{P} 4 \mathrm{P}$ payments were associated with physician burnout. Sense of calling, personally rewarding hours per day, income and work hours were associated with physician job dissatisfaction.
Table 3 presents the results of multivariate binary logistic regression analyses of physician burnout and job dissatisfaction. After adjusting for attitudes towards the NHI and demographic characteristics, there were significant associations of intrinsic and extrinsic motivators with physician burnout and job dissatisfaction. The physicians with a strong sense of calling were more likely to report less burnout (OR $0.16,95 \%$ CI 0.10 to 0.26 ) and job dissatisfaction (OR $0.35,95 \%$ CI 0.21 to 0.57 ). Having $5-7.5$ or $\geq 7.5$ personally rewarding hours each day was strongly associated with less physician burnout (OR 0.34, 95\% CI 0.20 to 0.58 and OR $0.25,95 \%$ CI 0.13 to 0.47 , respectively) and job dissatisfaction (OR $0.41,95 \%$ CI 0.24 to 0.68 and OR $0.46,95 \%$ CI 0.26 to 0.83 , respectively).

The physicians with more than 60 work hours per week were most likely to report burnout (OR 2.67, 95\% CI 1.54 to 4.63 ) and job dissatisfaction (OR 1.71, 95\% CI 1.05 to 2.79 ). The physicians treating $\mathrm{P} 4 \mathrm{P}$ patients and not receiving bonuses had $56 \%$ higher odds of burnout compared with those not treating P4P patients (OR 1.56, 95\% CI 1.02 to 2.38). The physicians caring for patients included in the bundled payment system and not sharing the losses had $41 \%$ lower odds of burnout compared with those not caring for the patients (OR $0.59,95 \%$ CI 0.36 to 0.97). The physicians with a monthly income of less than NT\$200 000 were more likely to report job dissatisfaction (OR $1.72,95 \%$ CI 1.14 to 2.61 ).

\section{DISCUSSION}

This national survey of physicians investigated the association of intrinsic and extrinsic motivators with physician burnout and job dissatisfaction. We found an association of intrinsic motivators (more sense of calling and personally rewarding hours per day) and extrinsic motivators (more normal work hours) with less physician burnout and job dissatisfaction. $\mathrm{P} 4 \mathrm{P}$ and bundled payments were associated with physician burnout. Not receiving $\mathrm{P} 4 \mathrm{P}$ bonuses from their organisations was associated with more physician burnout. Not sharing the losses from caring for patients included in the bundled payment system was associated with less physician burnout. Physicians with lower income levels were more likely to report job dissatisfaction.

The finding of the association of intrinsic motivators (more sense of calling and personally rewarding hours per day) with less physician burnout and job dissatisfaction was consistent with the results of Moller $e t a l^{14}$ and Tak et al. ${ }^{4}$ Our study confirms the organismic integration theory. Intrinsic motivation is an important construct to reflect the natural human propensity to learn and assimilate, and to allow the satisfaction of the basic human need for autonomy, competence and relatedness as a human is exposed to new ideas and performs new skills. ${ }^{12}$ Therefore, physicians who view the practice of medicine as a calling to help patients in need are less likely to feel burned out and dissatisfied with their work. In addition, a work environment that does not adequately support 
Table 3 Factors associated with physician burnout and job dissatisfaction $(n=1152)$

\begin{tabular}{ll} 
Burnout & Job dissatisfaction \\
\hline OR $(95 \% \mathrm{Cl})$ & OR $(95 \% \mathrm{Cl})$
\end{tabular}

Intrinsic motivators

Practice of medicine is a calling (ref: disagree)

$\begin{array}{lll}\text { Agree } & 0.16(0.10 \text { to } 0.26)^{\star \star \star} & 0.35(0.21 \text { to } 0.57)^{\star \star \star} \\ \text { Neutral } & 0.39(0.23 \text { to } 0.68)^{\star \star \star} & 0.52(0.30 \text { to } 0.90)^{\star}\end{array}$

Personally rewarding hours per day (ref: $<2.5)$

$\begin{array}{lll}2.5-5.0 & 0.59(0.36 \text { to } 0.99)^{\star} & 0.67(0.41 \text { to } 1.10) \\ 5.0-7.5 & 0.34(0.20 \text { to } 0.58)^{\star \star \star} & 0.41(0.24 \text { to } 0.68)^{\star \star \star} \\ \geq 7.5 & 0.25(0.13 \text { to } 0.47)^{\star \star} & 0.46(0.26 \text { to } 0.83)^{\star}\end{array}$

Meaningful, long-term relationships with patients (ref: most)

$\begin{array}{lll}\text { Many } & 0.62(0.32 \text { to } 1.22) & 1.01(0.54 \text { to } 1.89) \\ \text { A few } & 0.55(0.28 \text { to } 1.08) & 0.87(0.46 \text { to } 1.62) \\ \text { None } & 0.79(0.37 \text { to } 1.71) & 0.80(0.38 \text { to } 1.68)\end{array}$

Extrinsic motivators

Monthly income, NT\$ (ref: $\geq 300000)$

$<200000 \quad 1.21(0.77$ to 1.91$)$

$1.72(1.14 \text { to } 2.61)^{\star}$

200000-299999

1.20 (0.76 to 1.88$)$

1.43 (0.95 to 2.17$)$

Work hours a week (ref: $\leq 40)$

$\begin{array}{lll}41-59 & 2.12(1.30 \text { to } 3.47)^{\star \star} & 1.57(1.02 \text { to } 2.40)^{\star} \\ 60+ & 2.67(1.54 \text { to } 4.63)^{\star \star \star} & 1.71(1.05 \text { to } 2.79)^{*}\end{array}$

Am able to provide needed outpatient services (ref: disagree)

\begin{tabular}{|c|c|c|}
\hline Agree & $0.89(0.29$ to 2.71$)$ & $1.22(0.40$ to 3.76$)$ \\
\hline Neutral & 0.74 (0.23 to 2.39$)$ & $0.54(0.16$ to 1.75$)$ \\
\hline \multicolumn{3}{|c|}{ Am able to provide needed inpatient services (ref: disagree) } \\
\hline Agree & $1.18(0.34$ to 4.15$)$ & $0.36(0.13$ to 1.02$)$ \\
\hline Neutral & $1.15(0.31$ to 4.35$)$ & $0.42(0.13$ to 1.32$)$ \\
\hline Not applicable & 2.08 (0.46 to 9.35$)$ & 0.55 (0.15 to 2.01$)$ \\
\hline \multicolumn{3}{|l|}{ Pay-for-performance (ref: no) } \\
\hline Yes, receive bonus & $1.00(0.58$ to 1.71$)$ & $0.85(0.52$ to 1.39$)$ \\
\hline Yes, do not receive bonus & $1.56(1.02 \text { to } 2.38)^{\star}$ & $0.98(0.65$ to 1.48$)$ \\
\hline Yes, missing & $0.76(0.12$ to 4.92$)$ & $1.96(0.52$ to 7.43$)$ \\
\hline \multicolumn{3}{|l|}{ Bundled payments (ref: no) } \\
\hline Yes, be required to share losses & 0.59 (0.33 to 1.05$)$ & $0.96(0.58$ to 1.61$)$ \\
\hline Yes, be not required to share losses & $0.59(0.36 \text { to } 0.97)^{\star}$ & $0.78(0.49$ to 1.23$)$ \\
\hline
\end{tabular}

Attitudes towards the $\mathrm{NHI}$

The NHI is necessary for public health (ref: disagree)

$\begin{array}{lll}\text { Agree } & 0.53(0.31 \text { to } 0.91)^{\star} & 0.29(0.17 \text { to } 0.50)^{\star \star \star} \\ \text { Neutral } & 0.42(0.23 \text { to } 0.76)^{\star \star} & 0.41(0.23 \text { to } 0.74)^{\star \star}\end{array}$

The $\mathrm{NHI}$ is a favourable system to me (ref: disagree)

\begin{tabular}{lcc} 
Agree & $0.60(0.37 \text { to } 0.97)^{\star}$ & $0.29(0.19 \text { to } 0.46)^{\star \star \star}$ \\
Neutral & $0.72(0.45$ to 1.15$)$ & $0.61(0.39 \text { to } 0.95)^{\star}$ \\
Likelihood ratio test for model: $x^{2}$ & $290.11^{\star \star \star}$ & $283.699^{\star \star \star}$ \\
C index & 0.80 & 0.78 \\
\hline Hosmer and Lemeshow test: $x^{2}$ & 7.61 & 10.89 \\
\hline
\end{tabular}

Regressions adjusted for physician gender, age, practice site, specialties, years in practice and practice location. NT\$32 equaled \$1 in 2017. ${ }^{*} \mathrm{p}<0.05 ;{ }^{* *} \mathrm{p}<0.01 ;{ }^{* \star *} \mathrm{p}<0.001$.

$\mathrm{NHI}$, National Health Insurance; NT, New Taiwan. 
physicians' professional values might lead to physician burnout and job dissatisfaction when the physicians spend more time doing non-professional work such as medical documentation and insurance paperwork. ${ }^{14}$ The finding of the association between low-income levels and physician job dissatisfaction is consistent with those of previous studies. ${ }^{4738}{ }^{39}$ Moreover, and more importantly, we found that income was not associated with physician burnout. The organismic integration theory is, compared with the motivation-hygiene theory, also known as Herzberg's two-factor theory or Herzberg's dual-factor theory. ${ }^{40}$ Intrinsic motivators are similar to motivating factors, while extrinsic motivators are similar to hygiene factors. Motivating factors can increase job satisfaction. Poor hygiene factors such as low income can lead to job dissatisfaction, while better hygiene factors cannot lead to higher job satisfaction.

The finding of the association between longer work hours and physician job dissatisfaction is consistent with the results of Landon $e t a l^{27}$ and Christopher et $a l^{41}$ using nationally representative physician samples, and those of Leigh $e t a l^{15}$ using a nationally representative specialist sample. Moreover, and most importantly, the finding of the association between longer work hours and physician burnout is consistent with the result of Keeton $e t a t^{42}$ using a nationally representative sample of five specialists. Physicians with more than 60 work hours a week were most likely to report burnout and job dissatisfaction. ${ }^{1527}$ Physicians with longer work hours feel burned out through their perceived overload. ${ }^{43}$

This study found that the physicians who did not receive $\mathrm{P} 4 \mathrm{P}$ bonuses from their organisations were more likely to feel burned out compared with those not treating P4P patients. This finding is consistent with those of Smets et al. ${ }^{44}$ One possible explanation is that the physicians think their performance is not rewarded properly, and this may cause them to feel burned out based on the organismic integration theory. ${ }^{12}$ Moreover, the perceived inequity in their relationship with the organisation can also contribute to burnout. In return for their investments, physicians may expect reasonable financial compensation from their organisations. If these rewards are not provided, physicians may develop a negative attitude towards their organisations, ultimately leading to burnout. ${ }^{44}$ The physicians who treat $\mathrm{P} 4 \mathrm{P}$ patients make an effort to help them receive continuity of care; thus, the physicians expect that they will receive adequate rewards from their organisations.

This study found that the physicians who were not required to share the losses under bundled payments by their organisations were more likely to not feel burned out compared with those not treating bundled payment patients. The finding is similar to those of Reid et $a l^{16}$ regarding patient-centred medical homes. Patientcentred medical homes embrace a health professional team orientation grounded in evidence-based medicine and quality improvement, therefore leading to less burnout. ${ }^{16}$ The implementation of bundled payments encourages hospitals and physicians to use evidencedbased clinical pathways. ${ }^{17}{ }^{46}$ Prior research found that the adoption of clinical pathways decreased burnout ${ }^{18}$ because the primary focus of clinical pathways lies in redesigning work processes, reducing unnecessary variation and improving task-oriented coordination through the standardisation of care. ${ }^{47} 48$ Therefore, clinical pathways seem to be most effective for improving team-level taskwork and creating essential job resources that buffer the impact of increasing job demands in the current healthcare environment. ${ }^{18}$

There are two limitations of the present study. First, because the data are cross sectional, the results reflect the association of intrinsic and extrinsic motivating factors with physician burnout and job satisfaction, but causality could not be determined. The cross-sectional nature of this study requires future confirmation to better establish causality and to test strategies to reduce physician burnout and job dissatisfaction. Second, in alignment with the response rates of other national physician surveys $(17.0 \%-23.2 \%),{ }^{23} 4950$ the response rate in this study was only $17.3 \%$. However, non-response bias is less of a concern in surveys of physicians than it is in general population surveys, perhaps because physicians as a group are more homogeneous than are the general public in terms of demographics, knowledge and attitudinal characteristics. ${ }^{51}{ }^{52}$ Another factor contributing to the stability of the estimates may be the effectiveness of the non-response adjustment weightings for the sample of physician respondents. ${ }^{53}$ We constructed probability weights to adjust for potential bias. ${ }^{23} 5053$

Our national physician survey showed the association of intrinsic and extrinsic motivators with physician burnout and job satisfaction. Better intrinsic motivators (sense of calling and personally rewarding hours per day) are associated with not only decreased physician job dissatisfaction but also decreased burnout. Longer work hours are associated with physician burnout and job dissatisfaction. Not receiving $\mathrm{P} 4 \mathrm{P}$ bonuses from their organisations is associated with more burnout. Not being required to share the losses under bundled payments is associated with less burnout. Fostering a healthcare work environment that supports intrinsic motivation and improves work hours may reduce physician burnout and job dissatisfaction, and benefit their patients. Additionally, healthcare delivery organisations that improve workflow processes and enhance the direct engagement with patients may contribute to less physician burnout and job dissatisfaction. Rewarding physicians fairly and equitably may prevent them from feeling burned out. Value-based care delivery and payment model innovations, such as bundled payments, may encourage healthcare professionals to coordinate care through the standardisation of care to decrease burnout.

Contributors Y-CT and K-PC were responsible for the study concept and design. Y$\mathrm{CT}, \mathrm{Y}-\mathrm{YC}$ and $\mathrm{Y}-\mathrm{HC}$ were responsible for the acquisition, analysis and interpretation of data. Y-CT was responsible for the drafting of the manuscript. Y-CT, Y-YC, Y-HC 
and K-PC were responsible for the critical revision of the manuscript for important intellectual content. Y-CT and Y-YC were responsible for the statistical analysis. Y-CT was responsible for obtained funding. Y-CT and K-PC were responsible for the administrative, technical and material support. K-PC carried out the study supervision. All the authors read and approved the final manuscript.

Funding The study was supported by grants from the Ministry of Science and Technology (MOST105-2410-H-002-220-MY2) and the National Health Insurance Administration (MOHW106-NHI-S-114-113014).

Competing interests None declared.

Patient consent for publication Not required.

Ethics approval The study was approved by the National Taiwan University Hospital Institutional Review Board.

Provenance and peer review Not commissioned; externally peer reviewed.

Data availability statement № data are available. The data were deidentified participant data and were not publicly available.

Open access This is an open access article distributed in accordance with the Creative Commons Attribution Non Commercial (CC BY-NC 4.0) license, which permits others to distribute, remix, adapt, build upon this work non-commercially, and license their derivative works on different terms, provided the original work is properly cited, appropriate credit is given, any changes made indicated, and the use is non-commercial. See: http://creativecommons.org/licenses/by-nc/4.0/.

\section{ORCID iD}

Yu-Chi Tung http://orcid.org/0000-0001-9031-8749

\section{REFERENCES}

1 Berwick DM, Nolan TW, Whittington J. The triple aim: care, health, and cost. Health Aff 2008;27:759-69.

2 Rotenstein LS, Torre M, Ramos MA, et al. Prevalence of burnout among physicians: a systematic review. JAMA 2018;320:1131-50.

3 Eisenstein L, To Fight Burnout O. To fight burnout, organize. N Engl $J$ Med 2018;379:509-11.

4 Tak HJ, Curlin FA, Yoon JD. Association of intrinsic motivating factors and markers of physician well-being: a national physician survey. $J$ Gen Intern Med 2017;32:739-46.

5 Nishimura K, Nakamura F, Takegami M, et al. Cross-Sectional survey of workload and burnout among Japanese physicians working in stroke care: the nationwide survey of acute stroke care capacity for proper designation of comprehensive stroke center in Japan (JASPECT) study. Circ Cardiovasc Qual Outcomes 2014;7:414-22.

6 Chou LP, Li CY, Hu SC. Job stress and burnout in hospital employees: comparisons of different medical professions in a regional hospital in Taiwan. BMJ Open 2014:4:e004185.

7 Bodenheimer T, Sinsky C. From triple to quadruple aim: care of the patient requires care of the provider. Ann Fam Med 2014;12:573-6.

8 Sikka R, Morath JM, Leape L. The quadruple aim: care, health, cost and meaning in work. BMJ Qual Saf 2015;24:608-10.

9 West CP. Physician well-being: expanding the triple aim. J Gen Intern Med 2016;31:458-9.

10 Rathert C, Williams ES, Linhart H. Evidence for the quadruple aim: a systematic review of the literature on physician burnout and patient outcomes. Med Care 2018;56:976-84.

11 Haas JS, Cook EF, Puopolo AL, et al. Is the professional satisfaction of general internists associated with patient satisfaction? J Gen Intern Med 2000;15:122-8.

12 Ryan RM, Deci EL, Intrinsic DEL. Intrinsic and extrinsic motivations: classic definitions and new directions. Contemp Educ Psychol 2000;25:54-67

13 Judson TJ, Volpp KG, Detsky AS. Harnessing the right combination of extrinsic and intrinsic motivation to change physician behavior. JAMA 2015;314:2233-4.

14 Moller AC, Jager AJ, Williams GC, et al. US physicians' work motivation and their occupational health: a national survey of practicing physicians. Med Care 2019;57:334-40.

15 Leigh JP, Tancredi DJ, Kravitz RL. Physician career satisfaction within specialties. BMC Health Serv Res 2009;9:166.

16 Reid RJ, Coleman K, Johnson EA, et al. The group health medical home at year two: cost savings, higher patient satisfaction, and less burnout for providers. Health Aff 2010;29:835-43.

17 Tung YC, Chang HY, Chang GM. Impact of bundled payments on hip fracture outcomes: a nationwide population-based study. Int J Qual Health Care 2018;30:23-31.

18 Deneckere S, Euwema M, Lodewijckx C, et al. Better interprofessional teamwork, higher level of organized care, and lower risk of burnout in acute health care teams using care pathways: a cluster randomized controlled trial. Med Care 2013;51:99-107.

19 Nishishiba M, Jones M, Kraner M. Research methods and statistics for public and nonprofit administrators : a practical guide. Los Angeles: SAGE, 2014

20 Rea LM, Parker RA. Designing and conducting survey research : a comprehensive guide. San Francisco: Jossey-Bass, 2014.

21 Caress SM, Steinemann AC. A national population study of the prevalence of multiple chemical sensitivity. Arch Environ Health 2004;59:300-5.

22 Ahmad SS, Becker R, Chen AF, et al. EKA survey: diagnosis of prosthetic knee joint infection. Knee Surg Sports Traumatol Arthrosc 2016;24:3050-5.

23 Malhotra J, Wong E, Thind A. Canadian family physician job satisfaction - is it changing in an evolving practice environment? An analysis of the 2013 National Physician Survey database. BMC Fam Pract 2018;19:100.

24 Konrad TR, Williams ES, Linzer M, et al. Measuring physician job satisfaction in a changing workplace and a challenging environment. Med Care 1999;37:1174-82.

25 Stoddard JJ, Hargraves JL, Reed M, et al. Managed care, professional autonomy, and income: effects on physician career satisfaction. J Gen Intern Med 2001;16:675-84.

26 Bergus GR, Randall CS, Winniford MD, et al. Job satisfaction and workplace characteristics of primary and specialty care physicians at a bimodal medical school. Acad Med 2001;76:1148-52.

27 Landon BE, Reschovsky J, Blumenthal D. Changes in career satisfaction among primary care and specialist physicians, 19972001. JAMA 2003;289:442-9.

28 Ozyurt A, Hayran O, Sur H. Predictors of burnout and job satisfaction among Turkish physicians. QJM 2006;99:161-9.

29 Lee SY, Suh NK, Song JK. Determinants of public satisfaction with the National health insurance in South Korea. Int J Health Plann Manage 2009;24:131-46.

30 West CP, Dyrbye LN, Sloan JA, et al. Single item measures of emotional exhaustion and depersonalization are useful for assessing burnout in medical professionals. J Gen Intern Med 2009;24:1318-21.

31 West CP, Shanafelt TD, Kolars JC. Quality of life, burnout, educational debt, and medical knowledge among internal medicine residents. JAMA 2011;306:952-60.

32 Rasinski KA, Lawrence RE, Yoon JD, et al. A sense of calling and primary care physicians' satisfaction in treating smoking, alcoholism, and obesity. Arch Intern Med 2012;172:1423-4.

33 West CP, Dyrbye LN, Satele DV, et al. Concurrent validity of singleitem measures of emotional exhaustion and depersonalization in burnout assessment. J Gen Intern Med 2012;27:1445-52.

34 Allen T, Whittaker W, Sutton M. Does the proportion of pay linked to performance affect the job satisfaction of general practitioners? Soc Sci Med 2017;173:9-17.

35 West CP, Halvorsen AJ, Swenson SL, et al. Burnout and distress among internal medicine program directors: results of a national survey. J Gen Intern Med 2013;28:1056-63.

36 West CP, Dyrbye LN, Rabatin JT, et al. Intervention to promote physician well-being, job satisfaction, and professionalism: a randomized clinical trial. JAMA Intern Med 2014;174:527-33.

37 Little RJA. Statistical analysis with missing data. Hoboken, NJ: Wiley, 2002.

38 Menachemi N, Powers TL, Brooks RG. The role of information technology usage in physician practice satisfaction. Health Care Manage Rev 2009;34:364-71.

39 Leigh JP, Kravitz RL, Schembri M, et al. Physician career satisfaction across specialties. Arch Intern Med 2002;162:1577-84.

40 Herzberg F, Mausner B, Snyderman B. The motivation to work. Oxford, England: John Wiley, 1959

41 Christopher AS, Smith CS, Tivis R, et al. Trends in United States physician work hours and career satisfaction. Am J Med 2014;127:674-80.

42 Keeton K, Fenner DE, Johnson TRB, et al. Predictors of physician career satisfaction, work-life balance, and burnout. Obstet Gynecol 2007;109:949-55.

43 Shirom A, Nirel N, Vinokur AD. Overload, autonomy, and burnout as predictors of physicians' quality of care. $J$ Occup Health Psychol 2006;11:328-42.

44 Smets EMA, Visser MRM, Oort FJ, et al. Perceived Inequity: Does It Explain Burnout Among Medical Specialists?1. J Appl Soc Psychol 2004;34:1900-18.

45 Maslach C, Schaufeli WB, Leiter MP. Job burnout. Annu Rev Psychol 2001;52:397-422. 
46 Siddiqi A, White PB, Mistry JB, et al. Effect of bundled payments and health care reform as alternative payment models in total joint arthroplasty: a clinical review. J Arthroplasty 2017;32:2590-7.

47 Pronovost PJ, Berenholtz SM, Goeschel CA, et al. Creating high reliability in health care organizations. Health Serv Res 2006;41:1599-617.

48 Gittell JH . Coordinating mechanisms in care provider groups: relational coordination as a mediator and input uncertainty as a moderator of performance effects. Manage Sci 2002;48:1408-26.

49 Lee HY, Park SE, Park EC, et al. Job satisfaction and trust in health insurance review agency among Korean physicians. Health Policy 2008;87:249-57.
50 Shanafelt TD, Dyrbye LN, Sinsky C, et al. Relationship between clerical burden and characteristics of the electronic environment with physician burnout and professional satisfaction. Mayo Clin Proc 2016;91:836-48.

51 Kellerman SE, Herold J. Physician response to surveys. A review of the literature. Am J Prev Med 2001;20:61-7.

52 Field TS, Cadoret CA, Brown ML, et al. Surveying physicians: do components of the "Total Design Approach" to optimizing survey response rates apply to physicians? Med Care 2002;40:596-605.

53 Willis GB, Smith T, Lee HJ. Do additional recontacts to increase response rate improve physician survey data quality? Med Care 2013;51:945-8. 